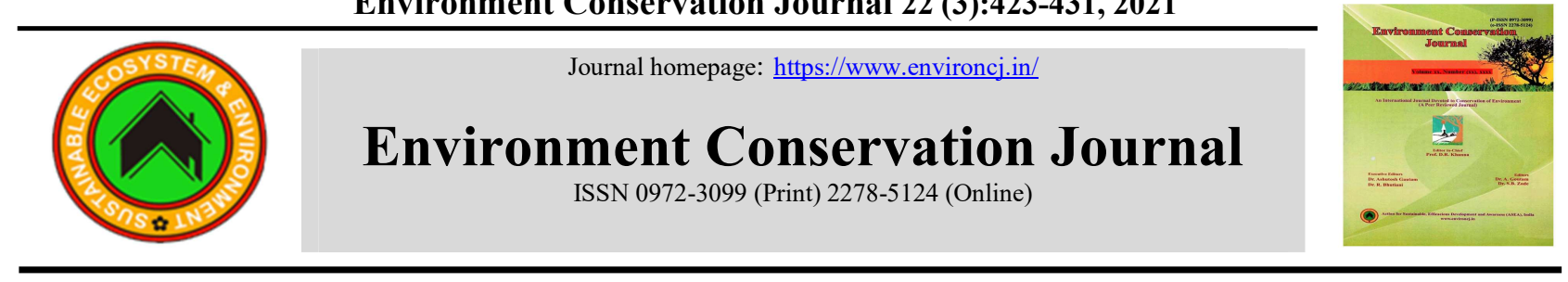

\title{
Tree species diversity in Kalidhar forest of western Shiwaliks, Jammu, JK (UT)
}

\author{
Sanjay Sharma \\ Department of Environmental Sciences, University of Jammu, Jammu, India \\ Dalip Kumar 四 \\ Department of Environmental Sciences, University of Jammu, Jammu, India
}

\begin{tabular}{|c|c|}
\hline ARTICLE INFO & ABSTRACT \\
\hline $\begin{array}{l}\text { Received : } 20 \text { September } 2021 \\
\text { Revised : } 15 \text { November } 2021 \\
\text { Accepted : } 17 \text { November } 2021 \\
\text { Available online: } 19 \text { December } 2021 \\
\text { Key Words: } \\
\text { Distribution } \\
\text { Dominance } \\
\text { Phytodiversity } \\
\text { Phytosociology } \\
\text { Species richness }\end{array}$ & $\begin{array}{l}\text { The present study was conducted in Kalidhar forest of western Shiwaliks, } \\
\text { Jammu, JK (UT), to assess the tree diversity and undertake phytosociological } \\
\text { analysis in three major land use (LU) classes i.e. Forest, Agriculture and Scrub } \\
\text { area. A total of } 70,50 \text { and } 50 \text { sample plots of } 0.1 \text { ha were laid respectively in } \\
\text { forests, scrub and agriculture } \mathrm{LU} \text { classes. The study revealed that in forests } \\
\text { possess a total } 39 \text { tree species belonging to } 19 \text { families and } 31 \text { genera, whereas, } \\
\text { in scrub and agriculture lands a total of } 9 \text { tree species ( } 8 \text { families and } 9 \text { genera) } \\
\text { and } 60 \text { tree species (26 families and } 46 \text { genera) were recorded respectively. } \\
\text { Mallotus philippensis was the most dense tree species with } 2.85 \text { individuals per } \\
\text { ha in forests followed by Pinus roxburghii } 2.06 \text { per hectare. In scrub and } \\
\text { agriculture land Acacia modesta and Grewia optiva were found the densest } \\
\text { species respectively. The value of Importance value index (IVI) was found } \\
\text { highest for Pinus roxburhii (44.63) in forests, whereas, respective values were } \\
\text { recorded highest for Syzygium cumini (82.64) and Grewia optiva (29.0) in scrub } \\
\text { and agriculture lands. Flacourtia indica and Pinus roxburghii showed random } \\
\text { distribution in forest and Syzygium cumini was also found to have random } \\
\text { distribution in the scrub lands. Contiguous distribution was found for all tree } \\
\text { species encountered in agriculture (LU) class. The diversity values of Shannon } \\
\text { Wiener and Simpson indices showed highest tree diversity in agriculture lands } \\
\text { with the values of } 3.19 \text { and } 0.07 \text { respectively followed by that in forests (2.47 } \\
\text { and } 0.14 \text { ). Tree species richness was found high in agriculture area with } \\
\text { Margalef's (59.86) and Menhinick's (1.80). }\end{array}$ \\
\hline
\end{tabular}

\section{Introduction}

India is a land of diverse nation with respect to its natural resources and traditions. Vegetation, especially trees are the most precious resource the nature has provided to us, as it caters to the essential requirements/needs of the human. The Indian Himalayan region is considered as the repository of biological and cultural diversity and supports about 18,440 species of plant, includes 1748 species of medicinal plants and 675 species of wild edibles (Negi and Gaur, 1994). Forests are one of the major sources of biodiversity and it is essential for human survival and economic well being and for the ecosystem function and stability. Forests of Himalaya play significant role for sustainable development of the region as they not only provide timber and resin to industries but also fulfills the basic needs of villagers such as fuel, small timber, fodder, and other minor products residing nearby areas. The knowledge of the floristic composition of a plant community is a prerequisite to understand the overall structure and function of any ecosystem (Gairola et al., 2010). Varied topographical features of Himalayan region supports unique and rich biodiversity elements ranging from genes and ecosystems. Significant work in the field of phytosociology and phytodiversity has also been done in the past few decades in the Himalayan state of Jammu and

Corresponding author E-mail: dalipdutta@yahoo.in

Doi: https://doi.org/10.36953/ECJ.2021.22349

This work is licensed under Attribution-Non Commercial 4.0 International (CC BY-NC 4.0)

(C) ASEA 
Kashmir by many workers including Sharma et al. (2008); Dangwal et al. (2012); Sharma and Raina (2013), Ahmed and Sharma (2014), Ghazal (2015), Sharma and Raina (2018). Sub tropical forest of Kalidhar region rich in floral wealth lie in the Shiwaliks hills of Jammu district in the Union Territory of Jammu and Kashmir. The rapid depletion of floristic diversity and changing pattern of vegetation due to various biotic and abiotic factors has promoted to carry out the qualitative and quantitative assessment of vegetation (Sharma et al., 2014). A sound understanding of phytosociology and the richness of species is necessary for appropriate conservation and restoration of the biological diversity. Thus keeping in view the present study has been carried out to analyze the composition, distribution and diversity of tree species in Kalidhar forest, western Shiwaliks, Jammu, J\&K.

\section{Material and Methods}

The detailed study was carried out Kalidhar range of Jammu Forest Division, a part of Western
Shiwaliks, J\&K. It is located between $32^{\circ} 47^{\prime}$ to $33^{\circ}$ $30^{\prime} \mathrm{N}$ latitude and $74^{\circ} 22^{\prime}$ to $74^{\circ} 48^{\prime} \mathrm{E}$ longitudes. The study area is about $30 \mathrm{~km}$ away from Jammu city and is surrounded by Rajouri district in north, Reasi district in east and International border with Pakistan in west (Figure 1). In the study, stratified random sampling was carried out. For sampling and data collection regarding trees in the three land use classes viz forest, scrub and agriculture land sample plots of size 0.1 ha were laid. In each sample plot plants with circumference at breast height $(\mathrm{CBH})$ greater than $30 \mathrm{~cm}$ (at $1.37 \mathrm{~m}$ from the ground) were considered as trees. The circumference of individual tree species was measured at breast height $(1.37 \mathrm{~m})$ above ground level by using measuring tape and height was measured with hypsometer. For the forest, Scrub and agriculture class total 70, 50 and 50 sample plots were laid respectively. The importance value index (IVI) was determined as the sum of the relative frequency, relative density and relative dominance (Curtis 1959).

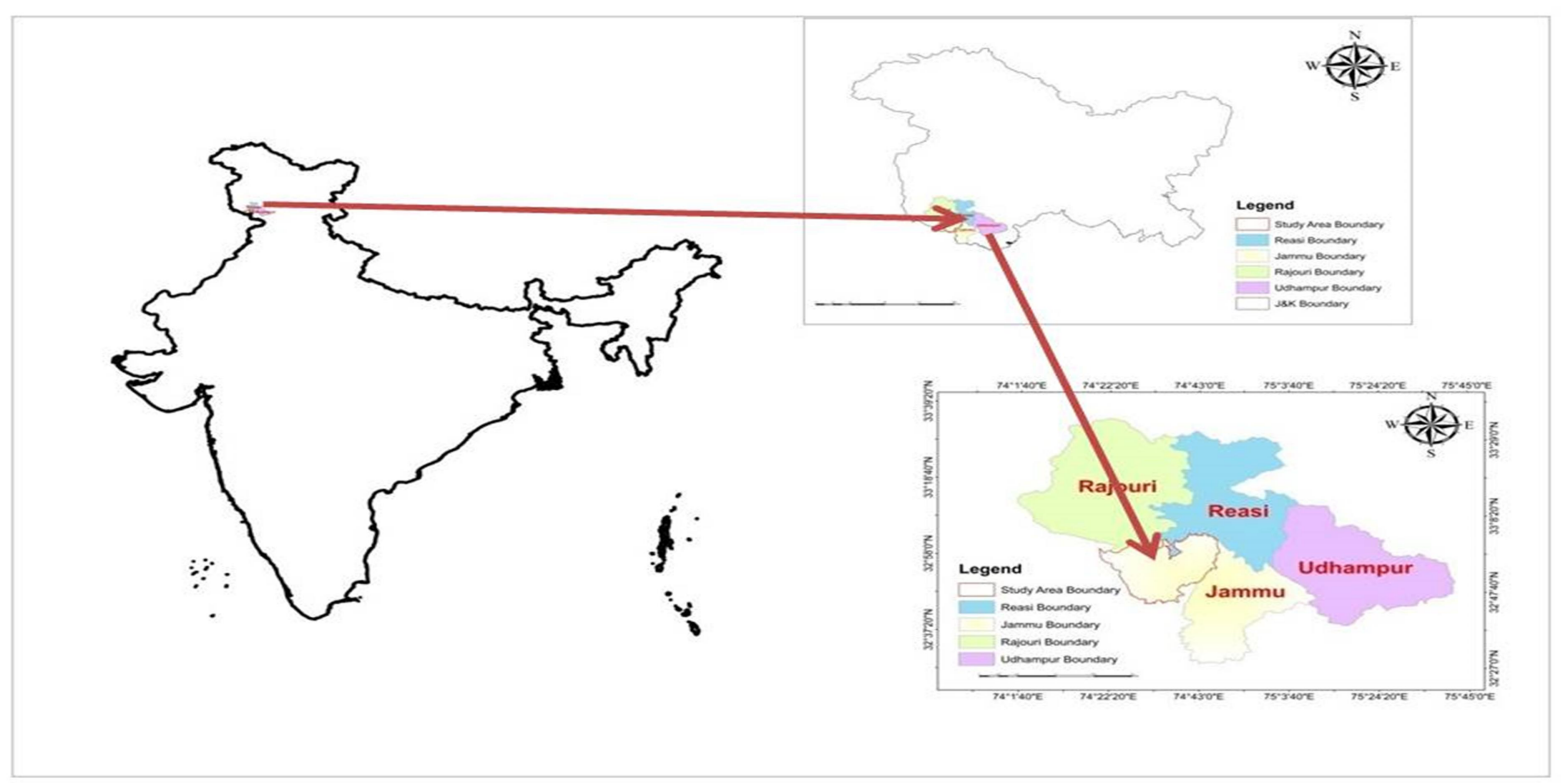

Figure 1: Location map of Kalidhar forest.

Basal area: Basal area refers to the ground actually penetrated by the stems and was used to calculate dominance of the tree species.

Basal area $=(\mathrm{CBH})^{2 / 4 \pi}$
Abundance to frequency ratio (A/F ratio) for different species was calculated to know the distribution pattern of the species. If, $<0.025$ it showed regular distribution, between $0.025-0.05$ indicates random distribution and $>0.05$ indicates contiguous distribution. Shannon-Wiener Index was used to calculate the species diversity in the 
community and was represented by $\mathrm{H}$ (Shannon and Wiener, 1963).

$$
H=-\Sigma P i \ln P i
$$

Where $\mathrm{Pi}=$ ni/N $\mathrm{ni}$ is number of the individuals of the species. $\mathrm{N}$ is total number of individuals of all species.

Concentration of dominance (Cd), Simpson's Index, was measured according to Simpson (1949).

$\mathrm{Ds}=\sum_{i=1}^{s}\left(\frac{\mathrm{ni}}{\mathrm{N}}\right)^{2}$

Where, $\quad \mathrm{n}=$ number of individuals of the species. $\mathrm{N}=$ total number of individuals of all species.

Richness was calculated by Margalef's Index (Da) (1968) and Menhinik's Index (Db) (1964) as given by Whittaker (1977).

$\mathrm{Da}=\mathrm{s}-\mathbf{1} / \ln (\mathbf{n})$

Where, $\quad \mathrm{s}=$ number of species. $\mathrm{n}=$ number of individuals.

$\mathrm{Db}=\mathbf{s} / \sqrt{\mathbf{n}}$

Where, $\quad \mathrm{s}=$ number of species $\mathrm{n}=$ number of individuals

Species diversity and concentration of dominance was computed by using Shannon-Weaver (1949) and Simpson indices (1949), respectively. Species richness was calculated using Menhinick's Index (1964) and Margalef's Index (1968).

\section{Results and Discussion}

Phytosociological analysis of tree species in forest area

The assessment of trees was carried out in three land use classes of the study area viz. forests, scrub and agriculture lands. The results of the study revealed that in forest a total of 39 tree species belonging to 19 families and 31 genera were recorded. The study showed that Mallotus philippensis was the most dense tree species with density of 2.85 individuals per hectare followed by Pinus roxburghii (2.06/ha). Although Mallotus philippensis is an associate of Pinus roxburghii but in the study area density of the former was found higher than the Pinus roxburghii. Some open patches of pine are found in the study area which indicates that there must be good population of Pine trees, which have reduced over the years due to anthropogenic pressure on these trees as pine is the most exploited species. A study conducted by Sharma and Kant (2014) in Jammu kandi shiwaliks have reported Mallotus philippensis as denser tree species as compared to Pinus rosburghii. According to them man made disturbances have impacted the vegetation pattern and distribution of tree species. The other tree species observed in the study with lesser density were Acacia modesta, Broussonetia papyrifera, Ficus religiosa, Oroxylum indicum, Psidium guajava Terminalia bellirica and Terminalia chebula. The Important Value Index (IVI) for Pinus roxburghii was observed (Table 1) to be highest (44.63) in the forest area followed closely by Mallotus philippensis (41.78). It has also been reported by Kumar (2010), Dangwal et al. (2012) and Sharma and Raina (2018) that the Pinus roxburghii and Mallotus philippensis are the dominant or co-dominant tree species.

\section{Phytosociological analysis of tree species in scrub area}

In the scrub areas, which are restricted to dry parts of the study area dominated by shrubs and with sparse population of trees such as Acacia modesta, Bombax ceiba, Syzygium cumini, Grewia optiva, etc. A total of 9 tree species belonging to 8 families and 9 genera were recorded. Sharma (2008) also observed 9 tree species in sub-tropical scrub in Birhun watershed. In the present study Acacia modesta was found the most dense tree species with value of 1.42 trees/2ha followed by Syzygium cumini 0.61 trees/ha. In a similar study carried out by Sharma and Kant (2014) also observed Acacia modesta as the most dense species with very density of 84.64 trees /ha. Whereas in a study conducted by Sharma (2008) observed Dalbergia sisoo most dense tree species followed by Acacia modesta with 0.57 and 0.42 trees /ha respectively. The importance value index among the tree species in scrub class was recorded highest 
for Syzygium cumini with IVI value of 82.64 show that in agriculture fields of the study area followed by Acacia modesta (76.93) (Table 2).

there are total 60 trees species belonging to 26

Phytosociological analysis of tree in agriculture families and 46 genera. The Grewia optiva was area

found the most dense tree species with density of

The prevalence of trees in the agriculture lands is 0.86 trees/ ha followed by Dalbergia sisso (0.33 there in the study area. The results of the study trees/ ha). A study conducted by Sharma and Kour

Table 1: Phytosociological parameters for trees in forest class of the study area

\begin{tabular}{|c|c|c|c|c|c|c|}
\hline SN & Name of sps & TBA $\left(\mathrm{m}^{2} / \mathrm{ha}\right)$ & $\mathbf{A B A} \pm \mathrm{STDV}$ & Density Trees/ha & $\mathrm{A} / \mathbf{F}$ ratio & IVI \\
\hline 1 & Acacia catechu & 0.98 & $0.02 \pm 0.01$ & 0.51 & 0.37 & 9.37 \\
\hline 2 & Acacia modesta & 0.02 & $0.02 \pm 0.00$ & 0.01 & 0.70 & 1.91 \\
\hline 3 & Acacia nilotica & 0.09 & $0.01 \pm 0.01$ & 0.06 & 0.54 & 2.56 \\
\hline 4 & Aegle marmelos & 0.03 & $0.02 \pm 0.00$ & 0.02 & 0.52 & 2.34 \\
\hline 5 & Albizzia lebbeck & 0.05 & $0.01 \pm 0.00$ & 0.04 & 0.87 & 1.90 \\
\hline 6 & Bauhinia purpurea & 0.03 & $0.01 \pm 0.01$ & 0.02 & 1.40 & 1.86 \\
\hline 7 & Bauhinia variegata & 0.12 & $0.01 \pm 0.00$ & 0.11 & 0.61 & 3.00 \\
\hline 8 & Bombax ceiba & 0.25 & $0.01 \pm 0.01$ & 0.19 & 0.14 & 5.89 \\
\hline 9 & Broussonetia papyrifera & 0.02 & $0.02 \pm 0.00$ & 0.01 & 0.60 & 1.97 \\
\hline 10 & Butea monosperma & 0.37 & $0.05 \pm 0.06$ & 0.06 & 0.20 & 7.14 \\
\hline 11 & Casearia tomentosa & 0.50 & $0.01 \pm 0.02$ & 0.27 & 0.14 & 7.59 \\
\hline 12 & Cassia fistula & 2.16 & $0.01 \pm 0.01$ & 1.51 & 0.06 & 28.66 \\
\hline 13 & Dalbergia sissoo & 0.20 & $0.02 \pm 0.03$ & 0.09 & 0.21 & 4.28 \\
\hline 14 & Desmodium oojeinense & 0.09 & $0.01 \pm 0.00$ & 0.07 & 0.70 & 2.49 \\
\hline 15 & Emblica officinalis & 0.32 & $0.02 \pm 0.01$ & 0.12 & 0.42 & 4.58 \\
\hline 16 & Ficus benghalensis & 1.25 & $0.21 \pm 0.26$ & 0.05 & 0.26 & 21.84 \\
\hline 17 & Ficus palmata & 0.01 & $0.01 \pm 0.00$ & 0.02 & 1.40 & 0.97 \\
\hline 18 & Ficus recemosa & 0.34 & $0.02 \pm 0.01$ & 0.16 & 0.39 & 4.82 \\
\hline 19 & Ficus religiosa & 0.03 & $0.03 \pm 0.00$ & 0.01 & 0.70 & 3.13 \\
\hline 20 & Flacourtia indica & 0.51 & $0.01 \pm 0.01$ & 0.46 & 0.05 & 13.26 \\
\hline 21 & Glochidion velutinum & 0.05 & $0.01 \pm 0.00$ & 0.03 & 0.70 & 2.02 \\
\hline 22 & Lannea coromandelica & 0.86 & $0.02 \pm 0.02$ & 0.39 & 0.12 & 10.12 \\
\hline 23 & Leucaena leucocephala & 0.19 & $0.01 \pm 0.01$ & 0.17 & 0.41 & 4.12 \\
\hline 24 & Mallotus philippensis & 3.46 & $0.01 \pm 0.01$ & 2.85 & 0.10 & 41.78 \\
\hline 25 & Mangifera indica & 0.42 & $0.11 \pm 0.11$ & 0.03 & 0.18 & 11.71 \\
\hline 26 & Mitragyna parvifolia & 0.04 & $0.02 \pm 0.00$ & 0.02 & 0.52 & 2.62 \\
\hline 27 & Olea cuspidate & 0.01 & $0.01 \pm 0.00$ & 0.02 & 1.40 & 1.04 \\
\hline 28 & Oroxylum indicum & 0.004 & $0.004 \pm 0.00$ & 0.01 & 0.70 & 0.74 \\
\hline 29 & Phoenix sylvestris & 0.13 & $0.01 \pm 0.01$ & 0.09 & 0.85 & 2.80 \\
\hline 30 & Pinus roxburghii & 18.24 & $0.07 \pm 0.07$ & 2.06 & 0.04 & 44.63 \\
\hline 31 & Psidium guajava & 0.01 & $0.01 \pm 0.00$ & 0.01 & 0.70 & 0.98 \\
\hline 32 & Syzgium cumini & 1.24 & $0.03 \pm 0.03$ & 0.29 & 0.09 & 10.77 \\
\hline 33 & Tectona grandis & 0.47 & $0.02 \pm 0.01$ & 0.22 & 0.76 & 5.12 \\
\hline 34 & Terminalia arjuna & 0.29 & $0.10 \pm 0.12$ & 0.02 & 0.52 & 10.34 \\
\hline 35 & Terminalia bellirica & 0.04 & $0.04 \pm 0.00$ & 0.01 & 0.70 & 4.69 \\
\hline 36 & Terminalia chebula & 0.01 & $0.01 \pm 0.00$ & 0.01 & 0.70 & 1.55 \\
\hline 37 & Toona ciliate & 0.07 & $0.01 \pm 0.00$ & 0.06 & 0.31 & 2.60 \\
\hline 38 & Trema politoria & 0.03 & $0.01 \pm 0.00$ & 0.03 & 0.70 & 1.50 \\
\hline \multirow[t]{2}{*}{39} & Wenlandia heynei & 0.91 & $0.01 \pm 0.02$ & 0.49 & 0.12 & 11.31 \\
\hline & Total & 33.82 & $1.02 \pm 0.87$ & 10.57 & - & 300 \\
\hline
\end{tabular}


(2014) revealed that Mangifera indica was the most Leucaena leucocephala with the value of 21.21 dense tree species in agriculture land (2.1 trees/ ha) (Table 3). A study carried out in Poonch by followed by Acacia nilotica (1.3 trees/ ha). In the Agriculture land the density values of tree species were less as compared to the forest area similar result was also reported by Ahmed and Sharma,2014. The IVI among the tree species in agriculture land was recorded highest for Grewia optiva withvalue of 29.0 followed by IVI of

Manzoor and Jazib, 2020 also found Grewia optiva as the most dense and dominant tree species with the density and IVI value of 3.88 and 16 respectively. Another study conducted by Sharma and Kour (2014) in Vijaypur, Samba, JK(UT) found maximum value of IVI (78.61) for Mangifera indica.

Table 2: Phytosociological parameters for tress in Scrub class of the study area

\begin{tabular}{|l|l|l|l|l|l|l|}
\hline SN & Name of species & TBA $\left.\mathbf{~ ( ~}^{\mathbf{2}} / \mathbf{h a}\right)$ & $\mathbf{A B A} \pm \mathbf{S t d v}$ & Density (Trees/ha) & A/F ratio & IVI \\
\hline 1 & Acacia modesta & 0.75 & $0.016 \pm 0.018$ & 1.420 & 0.08 & 76.93 \\
\hline 2 & Bombax ceiba & 0.0094 & $0.0047 \pm 0.0010$ & 0.061 & 0.09 & 10.34 \\
\hline 3 & Cassia fistula & 0.023 & $0.0058 \pm 0.0011$ & 0.123 & 0.05 & 17.48 \\
\hline 4 & Dalbergia sisso & 0.090 & $0.0075 \pm 0.0030$ & 0.370 & 0.06 & 30.37 \\
\hline 5 & Flacourtia indica & 0.035 & $0.0059 \pm 0.0023$ & 0.185 & 0.07 & 19.33 \\
\hline 6 & Grewia optiva & 0.0094 & $0.0047 \pm 0.0010$ & 0.061 & 0.09 & 10.34 \\
\hline 7 & $\begin{array}{l}\text { Lannea } \\
\text { coromandelica }\end{array}$ & 0.198 & $0.0123 \pm 0.0092$ & 0.493 & 0.08 & 38.24 \\
\hline 8 & Syzygium cumini & 0.96 & $0.0480 \pm 0.080$ & 0.617 & 0.04 & 82.64 \\
\hline 9 & $\begin{array}{l}\text { Wendlandia } \\
\text { heynei }\end{array}$ & 0.031 & $0.0051 \pm 0.0012$ & 0.185 & 0.27 & 14.28 \\
\hline \multicolumn{2}{|c|}{$\mathbf{2 . 1 1}$} & $\mathbf{0 . 1 1 0} \pm \mathbf{0 . 1 1 7}$ & $\mathbf{3 . 5 1 9}$ & ------ & $\mathbf{3 0 0}$ \\
\hline
\end{tabular}

Table 3: Phytosociological parameters for trees in Agriculture class of the study area

\begin{tabular}{|l|l|l|l|l|l|l|}
\hline SN & Name of species & TBA $\left(\mathbf{~ m}^{2} / \mathbf{h a}\right)$ & $\mathbf{A B A} \pm$ STDV & Density (Trees/ha) & A/F ratio & IVI \\
\hline 1 & Acacia catechu & 0.051 & $0.005 \pm 0.003$ & 0.036 & 0.281 & 3.006 \\
\hline 2 & Acacia modesta & 0.034 & $0.017 \pm 0.008$ & 0.008 & 0.250 & 3.619 \\
\hline 3 & Acacia nilotica & 0.108 & $0.009 \pm 0.006$ & 0.044 & 0.220 & 4.174 \\
\hline 4 & Aegle marmelos & 0.010 & $0.010 \pm 0$ & 0.004 & 0.500 & 2.195 \\
\hline 5 & Albizia lebbeck & 0.304 & $0.010 \pm 0.006$ & 0.120 & 0.104 & 8.136 \\
\hline 6 & Alstonia scholaris & 0.035 & $0.011 \pm 0.003$ & 0.012 & 0.375 & 2.807 \\
\hline 7 & Artocarpus lakucha & 0.114 & $0.022 \pm 0.014$ & 0.020 & 0.625 & 4.821 \\
\hline 8 & Azadirchta indica & 0.019 & $0.019 \pm 0$ & 0.004 & 0.500 & 3.548 \\
\hline 9 & Bauhinia purpurea & 0.249 & $0.006 \pm 0.005$ & 0.152 & 4.750 & 5.118 \\
\hline 10 & Bauhinia variegata & 0.021 & $0.010 \pm 0.011$ & 0.008 & 1.000 & 2.274 \\
\hline 11 & Bombax ceiba & 0.247 & $0.006 \pm 0.006$ & 0.148 & 0.072 & 9.466 \\
\hline 12 & $\begin{array}{l}\text { Broussonetia } \\
\text { papyrifera }\end{array}$ & 0.038 & $0.007 \pm 0.003$ & 0.020 & 0.625 & 2.351 \\
\hline 13 & Butea monosperma & 0.810 & $0.018 \pm 0.022$ & 0.180 & 0.900 & 8.560 \\
\hline 14 & $\begin{array}{l}\text { Callistemon } \\
\text { lanceolatus }\end{array}$ & 0.010 & $0.010 \pm 00$ & 0.004 & 0.500 & 2.195 \\
\hline 15 & Carica papya & 0.007 & $0.001 \pm 00$ & 0.020 & 2.500 & 1.024 \\
\hline 16 & Casearia tomentosa & 0.040 & $0.006 \pm 0.010$ & 0.024 & 0.333 & 2.587 \\
\hline 17 & Cassia fistula & 0.070 & $0.005 \pm 0.004$ & 0.056 & 0.143 & 4.288 \\
\hline
\end{tabular}

427

Environment Conservation Journal 


\begin{tabular}{|c|c|c|c|c|c|c|}
\hline 18 & Celtis australis & 0.013 & $0.006 \pm 0.001$ & 0.008 & 0.250 & 1.914 \\
\hline 19 & Citrus limetta & 0.005 & $0.001 \pm 0.0002$ & 0.012 & 1.500 & 0.857 \\
\hline 20 & Citrus limon & 0.003 & $0.001 \pm 0.0002$ & 0.008 & 1.000 & 0.787 \\
\hline 21 & Citrus medica & 0.011 & $0.002 \pm 0.0008$ & 0.016 & 0.500 & 1.451 \\
\hline 22 & Citrus pseudolimon & 0.013 & $0.002 \pm 0.0012$ & 0.024 & 0.188 & 2.168 \\
\hline 23 & Citrus sinensis & 0.069 & $0.002 \pm 0.0010$ & 0.112 & 0.875 & 4.181 \\
\hline 24 & Citrus nobilis & 0.001 & $0.001 \pm 00$ & 0.004 & 0.500 & 0.723 \\
\hline 25 & Cordia dichotoma & 0.020 & $0.006 \pm 0.0016$ & 0.012 & 0.375 & 2.009 \\
\hline 26 & Dalbergia sisso & 1.049 & $0.012 \pm 0.0146$ & 0.336 & 0.145 & 14.953 \\
\hline 27 & Eriobotrya japonica & 0.006 & $0.001 \pm 0.0002$ & 0.016 & 0.222 & 1.585 \\
\hline 28 & $\begin{array}{l}\text { Eucalyptus } \\
\text { citriodora }\end{array}$ & 0.091 & $0.013 \pm 0.0126$ & 0.028 & 0.219 & 4.026 \\
\hline 29 & Ficus auriculata & 0.019 & $0.009 \pm 0.0030$ & 0.008 & 1.000 & 2.114 \\
\hline 30 & Ficus benghalensis & 0.222 & $0.111 \pm 0.1189$ & 0.008 & 0.250 & 18.917 \\
\hline 31 & Ficus carica & 0.005 & $0.001 \pm 0.0002$ & 0.012 & 0.375 & 1.226 \\
\hline 32 & Ficus palmata & 0.098 & $0.003 \pm 0.0019$ & 0.112 & 0.115 & 6.562 \\
\hline 33 & Ficus recemosa & 0.037 & $0.018 \pm 0.0243$ & 0.008 & 0.250 & 3.850 \\
\hline 34 & Ficus religiosa & 0.171 & $0.021 \pm 0.0292$ & 0.032 & 0.250 & 5.481 \\
\hline 35 & Flacourtia indica & 0.100 & $0.003 \pm 0.0030$ & 0.108 & 0.080 & 7.138 \\
\hline 36 & Gmelina arborea & 0.008 & $0.008 \pm 00$ & 0.004 & 0.500 & 1.827 \\
\hline 37 & Grewia optiva & 1.403 & $0.006 \pm 0.0054$ & 0.864 & 0.148 & 29.000 \\
\hline 38 & $\begin{array}{l}\text { Lannea } \\
\text { coromandelica }\end{array}$ & 0.289 & $0.008 \pm 0.0055$ & 0.136 & 0.118 & 8.231 \\
\hline 39 & $\begin{array}{l}\text { Leucaena } \\
\text { leucocephala }\end{array}$ & 0.649 & $0.004 \pm 0.0049$ & 0.544 & 0.101 & 21.210 \\
\hline 40 & Litchi chinensis & 0.001 & $0.001 \pm 00$ & 0.004 & 0.500 & 0.671 \\
\hline 41 & Litsea chinensis & 0.026 & $0.006 \pm 0.0023$ & 0.016 & 0.500 & 2.051 \\
\hline 42 & $\begin{array}{l}\text { Mallotus } \\
\text { philippensis }\end{array}$ & 0.083 & $0.003 \pm 0.0026$ & 0.084 & 0.105 & 5.660 \\
\hline 43 & Mangifera indica & 1.935 & $0.030 \pm 0.0240$ & 0.252 & 0.079 & 16.983 \\
\hline 44 & Manilkara zapota & 0.003 & $0.003 \pm 00$ & 0.004 & 0.500 & 0.979 \\
\hline 45 & Melia azadirachta & 0.165 & $0.011 \pm 0.0030$ & 0.056 & 0.109 & 5.711 \\
\hline 46 & Morus alba & 0.227 & $0.009 \pm 0.0068$ & 0.100 & 0.195 & 6.253 \\
\hline 47 & Phoenix sylvestris & 0.016 & $0.005 \pm 0.0040$ & 0.012 & 0.375 & 1.809 \\
\hline 48 & $\begin{array}{l}\text { Phyllanthus } \\
\text { emblica }\end{array}$ & 0.169 & $0.010 \pm 0.0068$ & 0.064 & 0.500 & 4.425 \\
\hline 49 & Populus ciliata & 0.003 & $0.001 \pm 0.0003$ & 0.008 & 0.250 & 1.086 \\
\hline 50 & Prunus domestica & 0.002 & $0.002 \pm 00$ & 0.004 & 0.500 & 0.821 \\
\hline 51 & Prunus persica & 0.003 & $0.001 \pm 0.0003$ & 0.008 & 0.250 & 1.086 \\
\hline 52 & Psidium guajava & 0.050 & $0.002 \pm 0.0007$ & 0.072 & 0.250 & 3.964 \\
\hline 53 & Punica granatum & 0.005 & $0.001 \pm 0.0005$ & 0.012 & 0.375 & 1.223 \\
\hline
\end{tabular}


Tree species diversity in Kalidhar forest of western Shiwaliks

\begin{tabular}{|l|l|l|l|l|l|l|}
54 & Syzygium cumini & 0.362 & $0.014 \pm 0.0151$ & 0.100 & 0.074 & 8.709 \\
\hline 55 & Tectona grandis & 0.089 & $0.005 \pm 0.0049$ & 0.060 & 7.500 & 2.639 \\
\hline 56 & Terminalia bellirica & 0.311 & $0.025 \pm 0.0144$ & 0.048 & 0.375 & 6.573 \\
\hline 57 & Toona ciliata & 0.349 & $0.016 \pm 0.0083$ & 0.084 & 0.105 & 7.758 \\
\hline 58 & Wendlandia heynei & 0.007 & $0.003 \pm 0.0030$ & 0.008 & 1.000 & 1.079 \\
\hline 59 & Ziziphus maurtiana & 0.092 & $0.009 \pm 0.0064$ & 0.040 & 1.250 & 3.043 \\
\hline 60 & $\begin{array}{l}\text { Ziziphus } \\
\text { nummularia }\end{array}$ & 0.299 & $0.008 \pm 0.0052$ & 0.140 & 0.273 & 7.067 \\
\hline & Total & $\mathbf{1 0 . 6 7 9}$ & $\mathbf{0 . 6 1 3} \pm \mathbf{0 . 4 4 6}$ & $\mathbf{4 . 4 5 1 5 9 7}$ & ----- & $\mathbf{3 0 0}$ \\
\hline
\end{tabular}

Table 4: Diversity Indices for Trees in Forest, Scrub and Agricultural area

\begin{tabular}{|l|l|l|l|lc|}
\hline Land form & $\begin{array}{l}\text { Margalef's } \\
\text { index (Da) }\end{array}$ & $\begin{array}{l}\text { Menhinick's } \\
\text { index (Db) }\end{array}$ & $\begin{array}{l}\text { Shannon-Wiener's } \\
\text { index (H) }\end{array}$ & $\begin{array}{l}\text { Simpson's index } \\
\text { (Ds) }\end{array}$ & 0.14 \\
\hline Forest & 38.86 & 1.07 & 2.47 & & 0.23 \\
\hline Scrub & 8.79 & 0.84 & 1.75 & 0.07 \\
\hline Agriculture & 59.86 & 1.80 & 3.19 & & \\
\hline
\end{tabular}

\section{Distribution Pattern of tree species}

Distribution pattern of tree species in the study area was mainly contagious in all the three classes viz. forest, scrub and agriculture. Odum (1971) also observed that contiguous is the most common pattern in nature and it is due to small significant variations in the environment. Among tree species in forest of the study area, Flacourtia indica and Pinus roxburghii show random distribution. In contrary the study conducted elsewhere by Ahmed and Sharma (2014) reported Ficus recemosa and Pyrus pashia were randomly distributed in the forest. In the scrub of the study area only Syzygium cumini was randomly distributed. In case of agricultural class of the study area all the species showed contagious distribution pattern. Whereas regular distribution is rare due to severe competition between the individuals exists.

\section{Diversity analysis}

The study regarding tree diversity using ShannonWiener and Simpson indices and species richness using Margalef's and Menhinick's indices was carried out. The results showed that the tree diversity in agriculture land use was highest with Shannon-Wiener and Simpson indices values of 3.19 and 0.07 respectively. The high value of Shannon Wiener index in agriculture land can be attributed to cultivation of various trees especially fruit and other multipurpose tree species (Ahmed and Sharma, 2014). The Shannon- Wiener index values for trees in the forest and scrub were found to be 2.47 and 1.75 respectively, whereas the respective values of Simpson index for the forest and scrub classes were observed as 0.14 and 0.23 . The Shannon Wiener index values obtained in the present study are comparable to the value of 2.78 reported by Kumar and Raina (2012) in forests of Kishtwar J\&K, 3.16 in Lamberi forest range, Rajouri (Sharma, 2012) and 2.62 by in Ramnagar Wildlife sactuary, Jammu (Ghazal, 2015). The Simpson Index values found in the study are in accordance with the findings i.e. 0.17 observed by Dangwal et al., (2012) in Nowshera block of Rajouri district and in range of 0.07 to 0.63 found by Bijalwan, (2010) in different districts of Madhya Pradesh, India, in the areas of high interference by human beings. In case of scrub class the values of Simpson index was observed to be 0.23 (Table 4).

The values of Margalef and Menhinick indices for tree species richness were also found highest for agriculture class with the values of 59.86 and 1.80 , respectively, followed by values of 38.86 and 1.07 for trees in forest class The observation made by 
Ahmed and Sharma (2014) in Ponda watershed also showed the maximum values of tree species richness in the agriculture area. In scrub class the respective values of Margalef and Menhinick indices found were 8.79 and 0.84 for trees respectively. In similar studies conducted by various authors such as Sharma and Kant, 2014; Ahmed and Sharma, 2014 and Ghazal, 2015 obtained value of 16.46 and $1.21 ; 7.13$ and 2.16 ; 3.68 and 1.86 respectively.

\section{Conclusion}

The phytosociological and tree diversity analysis of three land use classes in the study area i.e. forests, scrub and agriculture lands, revealed that there is a big gap between the values of various parameters like IVI, density, A/F ratio among these classes. The diversity was found highest in agriculture lands because of plantation of different multipurpose tree species. There are many tree species having very low values of IVI and other parameters and these species deserve more attention for conservation. Thus the phytodiversity studied is in under great anthropogenic pressure.

\section{Acknowledgement}

The authors are highly thankful to Department of Environmental Sciences, University of Jammu for their necessary facilities and encouragement.

\section{References}

Ahmed, J., \& Sharma, S. (2014). Spatial pattern, diversity and phytosociological analysis of woody plant species in Ponda Watershed, Rajouri, J\&K, India. International Journal of Current Research, 6(6), 7022-7027.

Bijalwan, A. (2010). Structure, composition and diversity of degraded dry tropical forest in Balamdi Watershed of Chhattisgarh plain, India. Journal of Biodiversity, 1(2), $119-124$

Curtis, J. T. (1959). The vegetation of Wisconsin: an ordination of plant communities. University of Wisconsin Pres.

Dangwal, L. R., Singh, T., Singh, A., \& Sharma, A. (2012). Species composition of woody plants in forest of block Nowshera, district Rajouri (J\&K), India. International Journal of Current Research, 4(5), 5-10.

Gairola, S., Sharma, C. M., Rana, C. S., Ghildiyal, S. K., \& Suyal, S. (2010). Phytodiversity (Angiosperms and Gymnosperms) in Mandal-Chopta forest of Garhwal
Himalaya, Uttarakhand, India. Nature and Science, 8(1), 117.

Kumar, D., (2010). Tree and shrub diversity in Mehari watershed of Rajouri, J\&K. M.Sc. dissertation, Department of Environmental Sciences, University of Jammu.

Kumar, R., \& Raina, A. K. (2012). Phytosociology and species diversity in the catchment of Ratle hydro-electric project, District Kishtwar-J\&K (India). Environment Conservation Journal, 13(3), 141-145.

Manzoor, J., \& Jazib, M. J. (2020). Distribution Pattern and Phytosociological Study of Agroforestry Trees in Poonch District of Jammu and Kashmir, India. Journal of Biodiversity Conservation and Bioresource Management, 6(2), 77-82.

Margalef, R. (1968). Perspectives in ecological theory. Kashmir, India.

Menhinick, E. F. (1964). A comparison of some speciesindividuals diversity indices applied to samples of field insects. Ecology, 45(4), 859-861.

Negi, K. S., \& Gaur, R. D. (1994). Principal wild food plants of western Himalaya, Uttar Pradesh, India. Hishar Plants of Indian Subcontinent, Bishan Singh Mahendra Pal Singh, Dehradun, India, 1-78.

Odum, E. P., \& Ecologia, W. B. (1971). Saunders Company. WB Fundamentals of Ecology. 3rd Edition. Philadelphia, Pennsylvania, 574.

Shannon, C. E., \& Weaver, W. (1949). The mathematical theory of com-munication. Urbana: University of Illinois Press, 96.

Shannon, C. E., \& Wiener, W. (1963). The mathematical theory of Communication University. Urbana: Illinois Press.

Sharma, J., \& Raina, A. K. (2018). Quantitative analysis, distributional pattern and species diversity of woody plant species of Lamberi Forest Range, Rajouri, J\&K, India. Journal of Applied and Natural Science, 10(1), 522527.

Sharma, J., (2012). Phytodiversity and phytosociology of Lamberi forest range, Rajouri, J\&K (Unpublished). M.Phil. thesis).University of Jammu, J\&K, India.

Sharma, N., \& Kant, S. (2014). Vegetation structure, floristic composition and species diversity of woody plant communities in sub-tropical Kandi Siwaliks of Jammu, J \& $\mathrm{K}$, India. International Journal of Basic and Applied Sciences, 3(4), 382.

Sharma, N., \& Raina, A. K., (2013). Composition, structure and diversity of tree species along an elevation gradient in Jammu province of North- Western Himalyas, Jammu and 
Kashmir Journal of Biodiversity and Environmental Science, 3(10), 12-23.

Sharma, P., Rana, J. C., Devi, U., Randhawa, S. S., \& Kumar, R. (2014). Floristic diversity and distribution pattern of plant communities along altitudinal gradient in Sangla Valley, Northwest Himalaya. The Scientific World Journal, 2014.

Sharma, R. K., Sankhayan, P. L., \& Hofstad, O. (2008). Forest biomass density, utilization and production dynamics in a western Himalayan watershed. Journal of Forestry Research, 19(3), 171-180.
Sharma, S. (2008). Conservation and management of natural resources in Birhun watershed, $J \& K$, using Remote Sensing and GIS Techniques (Doctoral dissertation, D. Phil, Thesis submitted to HNB Garhwal University).

Sharma, S., \& Kour, K. (2014). Tree diversity in rural area of block Vijaypur, Samba, J\&K. International Journal of Environmental Sciences, 4(6), 1114.

Simpson, E. H. (1949). Measurement of diversity. nature, 163(4148), 688-688.

Whittaker, R. H., \& Levin, S. (1977). The role of mosaic phenomena in natural communities. Theoretical population biology, 12(2), 117-139. 